East African Journal of Science, Technology and Innovation, Vol. 1 (3): 2020.

This article is licensed under a Creative Commons license, Attribution 4.0 International (CC BY 4.0)

\title{
A Comparative study of the Sero-prevalence of Peste Des Petits Ruminants Virus among Districts of Different Agro-Ecological Zones in Tanzania
}

\author{
${ }^{1 *}$ MDETELE D., ${ }^{2 S E T H ~ M ., ~}{ }^{3}$ KABULULU M., ${ }^{1 M I S I N Z O ~ G ., ~}{ }^{1}$ KOMBA E
}

\author{
${ }^{1}$ Southern African Centre for infectious diseases/SACIDS Foundation for one health, Sokoine University of Agriculture, P.O. Box 3015, \\ ${ }^{2}$ National Institute for Medical Research, Tanga Medical Research Centre, P. O. Box 5004, Tanga, Tanzania. \\ ${ }^{3}$ Tanzania Livestock Research Institute - Uyole, P.O Box 6191, Mbeya, Tanzania \\ *Corresponding author: daniel.mdetele@sacids.org
}

\begin{abstract}
Peste des petits Ruminants (PPR), a disease affecting sheep and goats, was confirmed in Tanzania in the year 2018. Since then the disease has continued to spread into different districts, causing significant socio-economic losses to livestock keepers. This study aimed at determining the sero-prevalence of PPR in 32 districts from the coastal, semi-arid and plateau ecological zones, respectively. Sera samples were collected from sheep and goats, and analysed by competitive Enzyme Linked Immunosorbent Assay (c-ELISA). Findings indicated that six (18.8\%) districts had very high PPR sero-prevalence of which four (66.7\%; Chamwino, Kondoa, Mvomero and Kilosa) belong to the semi-arid ecological zone and two (33.3\%; Bagamoyo and Mkuranga) to the coastal ecological zone. Three districts (9.4\%) had high PPR sero-prevalence, all from the semi-arid ecological zone. Twelve districts had low PPR seroprevalence of which two $(16.7 \%)$ were from semi-arid, one $(8.3 \%)$ from coastal and nine $(75.0 \%)$ from plateau ecological zones. A zero PPR sero-prevalence was recorded in three districts and eight districts from semi-arid and plateau ecological zones, respectively. There was a statistically significant difference in sero-positivity between the different ecological zones, $\chi^{2}(2)=9.121, p=0.010$, with a mean rank sero-positivity of $24.7 \%$ for coastal zone, $12.0 \%$ for plateau and $20.8 \%$ for semi-arid zone. Post hoc pairwise comparison with Bonferroni correction for multiple tests showed a statistically significant difference between plateau and semi-arid zones $(\mathrm{p}=0.032)$. Although the coastal zone had a higher mean rank positivity than the plateau zone, the difference was not statistically significant $(p=0.083)$. The study suggests a zonal predisposition of PPR sero-prevalence with districts in the semi-arid and coastal zones having significantly higher values compared to those in the plateau ecological zones. Efforts for control of the disease need to concentrate in those two high risk ecological zones.
\end{abstract}

Keywords: Ecological zones; PPR; Sero-prevalence; Tanzania

Cite as: Mdetele et al, 2020 A Comparative study of the Seroprevalence of Peste Des Petits Ruminants Virus among Districts of Different Agro-Ecological Zones in Tanzania; East African Journal of Science, Technology and Innovation 1(3) $\begin{array}{ll}\text { Received: } & 20 / 04 / 20 \\ \text { Accepted: } & 03 / 06 / 20 \\ \text { Published: } & 24 / 06 / 20\end{array}$

\section{Introduction}

Small ruminants play an important role in agricultural food production in developing countries (Devendra \& McLeroy, 1982), including Tanzania (Shirima, 2005). In these countries, the sector also plays a crucial role in sustainable employment, contributing significantly to the economies and livelihoods of the smallholder farmers. However, the small ruminant industry in developing countries is constrained by factors such as high rates of infectious diseases as well as poor nutrition and marketing systems. Of the known infectious diseases, peste des petits ruminants (PPR) and contagious caprine pleuro-pneumonia (CCPP) are the most serious ones (Bölske et al., 1996; Malik et al., 2011; Rurangirwa et al., 1991); because of the associated high morbidity and mortality rates (Baron et al., 2016; Kipronoh et al., 2016; Singh, 2011). These two diseases pose a great threat to the livelihoods of many rural 
small holder ruminant keepers, most of them being drawn from poor backgrounds (Diallo, 2006; El Hassan et al., 1984). Other important diseases include goat/sheep pox, contagious ecthyma, dermatophilosis and those caused by parasites (both internal and external).

Peste des petits ruminants (PPR) is a highly contagious and infectious viral disease of small ruminants (both domestic and wild) and camels (Khalafalla et al., 2010; Saeed et al., 2015; Zakian et al., 2016). It is an economically significant transboundary disease of sheep and goats causing significant losses among these animal populations. It is a major hindrance to smallruminant production in areas where it occurs. The disease was first described in Côte d'Ivoire by Gargadennec and Lalanne in the year 1942. Currently, PPR is known to be present in a broad belt of sub-Saharan Africa, Arabia, the Middle East and Southern Asia. In these regions, the disease assumes an endemic pattern thereby causing severe impacts to the small ruminant industry. However, outbreaks of the disease have been reported in Turkey, China, Mongolia and Kazakhstan in recent years; indicating an expansion of its coverage resulting into a marked rise in the global incidence (Bao et al., 2011; Kock et al., 2015; Orynbayev et al., 2016; Shatar et al., 2017). The transboundary nature of the disease explains its potential for such an expansion and a rise in its incidence.

Primarily, PPR affects goats and sheep where it exhibits different levels of virulence, manifested by severity in the clinical presentation and time course of the disease. In most outbreaks of the disease, goats are severely affected while sheep are less severely affected, undergoing a mild form of the disease (Chauhan et al., 2009; Truong et al., 2014). In a few occasions, cattle and pigs can also be infected with the PPR virus (PPRV), although these animal species are not susceptible to clinical disease, and so infections in these animal species go without showing any symptoms (Anderson \& McKay, 1994; Kumar et al., 2013; Sen et al., 2014; Taylor \& Barrett, 1946). On the other hand, antelopes and other wild small ruminant species are severely affected by the PPRV, while the outcome of infection with the virus in other wild animal species is the development of antibodies without a clinical disease (Kinne et al., 2010; Mahapatra et al., 2015; Munir, 2014a; Orynbayev et al., 2016).

PPR is a contagious disease and therefore its transmission requires close contact between infected and susceptible animals. PPRV concentration is normally high in the exhaled air and body fluids such as oral and nasal discharges, urine and faeces of the infected animals (Wernike et al., 2014). These discharges from the eyes, nose, mouth and faeces of an infected animal contain viruses, which are normally released into the environment when these affected animals cough, sneeze or defecate (Baron et al., 2014; Michael et al, 2015). Contact with those infectious materials is the most important way of transmission of the disease to healthy susceptible animals (Kihu et al., 2016; Couacy-Hymann et al., 2007; Fournié et al., 2018). PPRV is primarily transmitted via the respiratory route among animals living in close proximity. Thereafter, the virus spreads to other tissues of the body via regional lymph nodes, then infects the lymphocytes and infection spreads throughout the body via both the lymphatic and vascular systems. The virus is excreted by sick sheep and goats from one to two days prior to the development of clinical signs up to at least 10 days after the onset of signs in ocular, nasal and oral secretions at varying levels, and can be detected in faeces after the onset of signs for at least 10 days. PPRV does not survive long in the environment so indirect transmission plays a minor role and there is no evidence of a carrier state in infected animals.

Trade in live sheep and goats at markets where animals from different sources are brought into close contact increases chances for PPR transmission when the groups contain infected animals (Abubakar \& Munir, 2014; Baron et al., 2017; Munir, 2014b; Swai et al., 2009). PPRV is now endemic in most of Africa and throughout Asia, where it is one of the main constraints to small ruminant production, trade and welfare. Therefore, it is a threat to food security and livelihoods of the poorest communities, to whom sheep and goats are often an important asset as most of the families can afford them as opposed to cattle (Baazizi et al., 2017; FAO \& OIE, 2015). Moreover, spill-over of the PPRV from domestic animals to wildlife populations could result into serious concerns to the conservationists as it threatens the existence of endangered species (Kock et al., 2015; Munir, 2014a; Travis, Watson, \& Tauer, 2011), thereby disturbing ecologies.

In Tanzania, several studies have been 
conducted on PPR and results suggest that the disease is widespread in the country, thereby assuming endemicity. The studies are however fragmented and were not planned to provide a comprehensive picture of the country in relation to occurrence and distribution of the disease. Moreover, majority of these studies did not look into predictors for occurrence of the disease which is key in supporting endeavours to plan and develop disease control strategies. This in turn calls for more epidemiological studies which would cover aspects of analysis of risk factors responsible for occurrence and persistence of the disease among the rural farmer's goat and sheep populations.

Several studies have linked the occurrence and dynamics of infectious diseases in different animal populations to prevailing ecological features (Woma et al., 2016). The objective of this study was to estimate PPR sero-prevalence in selected districts from Tanzania, in relation to ecological zones in order to understand the variation in magnitude of the disease between the zones. Results of the study were intended to inform disease control strategies especially in helping to make rational decisions in allocation of limited resources by making use of the available epidemiological information.

\section{Material and methods}

\section{Study areas}

Tanzania is divided into eight different ecological zones that include the coastal, arid lands, semi-arid land, plateaux, Northern highlands, alluvial plains, Southern and Western highlands, with different physiological properties. Traditionally, in the past, there were areas for pastoralists, agro-pastoralists and crop producers in association with characteristics of these ecological zones to support their activities. Because of climate change which eventually resulted into shrinking of the grazing land, the importance of sheep and goats among pastoralists has increased significantly. As well, shifting of pastoralists and agro-pastoralists from their traditional territories has become inevitable. The current study therefore focused on three ecological zones in which small ruminants production is more prominent. Districts with large populations of goats and sheep were selected from the study zones, with the help of the District livestock offices in the respective zones. The Districts were selected from a list of those in which there had been no previous studies on the occurrence of PPR. Eventually, this study involved 32 districts of which three (9.4\%), $12(37.5 \%)$ and 17 (53.1\%) were from the coast, semi-arid and plateau ecological zones, respectively.

\section{Sampling procedure and sample collection}

This study was carried out using stored serum samples collected from goats and sheep in the year 2013 under the United Nations Food and Agriculture Organization (FAO) project: Emergency assistance for early detection and control of PPR (PPR) TCP/URT/3302 (E). During implementation of the project, sampling was performed in 32 different districts in which PPR surveillance activities had never been carried out before, to assess if they have ever encountered the disease after the first outbreak of the disease in Tanzania in the year 2008. Staff in the respective Zonal Veterinary Investigation Centres (VICs) were involved in collection of the samples. The selection of Districts to be involved in the survey was purposively based on large populations of goats and sheep. Ten villages from each selected district and ten livestock keepers from each selected village were randomly selected for animal sampling. Five animals were selected for sampling from each selected herd using random procedures. From each animal approximately $5 \mathrm{ml}$ of blood were collected from the jugular vein into a plain vacutainer tube. Blood samples were left to settle over night at room temperature before serum was harvested and stored into $2.5 \mathrm{ml}$ cryovials at $4^{\circ} \mathrm{C}$ in the field and later at respective VIC at $-20^{\circ} \mathrm{C}$ before shipping to Sokoine University of Agriculture (SUA) for laboratory analysis. At SUA the samples were stored at $-80^{\circ} \mathrm{C}$ freezers up to the time of laboratory analysis.

\section{Laboratory analysis of the collected serum samples}

The detection of antibodies to PPRV from the collected serum samples was done using cELISA. The test is based on the competition between the anti-PPR monoclonal antibodies and antibodies in the serum sample binding to the PPR antigen. The presence of antibodies to PPRV serum sample outcompete and block reactivity of the monoclonal antibody resulting in the reduction in expected colour (signal) following the addition of enzyme labelled antimouse conjugate and substrate or chromogen solution. The assay was performed according to the general principle of c-ELISA as previously 
described by Anderson \& McKay (1994). Briefly, Nunc Maxisorb 96-well microtitre plates were used for all the assays. Volumes of $50 \mathrm{ul}$ of serum were used throughout the test after thawing. The PPR antigen was adsorbed to the plate using phosphate buffered saline (PBS), and all the other reagents were added in blocking buffer (PBS supplemented with $0-1 \%[\mathrm{v} / \mathrm{v}]$ Tween-20 and $0.3 \% \quad[\mathrm{v} / \mathrm{v}]$ normal bovine serum). All incubation steps were for $1 \mathrm{~h}$ at $37^{\circ} \mathrm{C}$ on an orbital shaker. Plates were washed three times after each incubation step by flooding them with PBS then emptying. Mouse immunoglobulin was detected using rabbit antimouse immunoglobulin conjugated to horseradish peroxidase (HRPO). Hydrogen peroxide/orthophenylene diamine (OPD) was used as a substrate/chromogen. Samples with percentage inhibition values of more than $50 \%$ were considered positive.

\section{Statistical analysis}

Data were analyzed using Statistical Package for Social Sciences (SPSS ${ }^{\circledR}$ ) software version 21. Descriptive statistics were computed to determine sero-prevalences for districts in respective ecological zones. A non-parametric test - Kruskal Wallis $\mathrm{H}$ was used to determine whether there existed a statistically significant difference in district-level sero-prevalence between the three ecological zones. Post hoc pairwise comparisons were performed, with Bonferroni correction for multiple comparisons, to indicate which ecological zones differed in sero-prevalence. For the purpose of this study sero-prevalences of PPR at district level were categorized as very high $(>20 \%)$, high $(11-20 \%)$ and low (1-10\%). Quantum Geographical Information System (QGIS) was used to create a map displaying the 32 districts involved in this study.

\section{Results}

The study involved 32 districts of which three $(9.4 \%)$ were from coast ecological zone, 12 $(37.5 \%)$ from the semi-arid ecological zone and $17(53.1 \%)$ from the plateau ecological zone. The mean rank sero-positivity of the three ecological zones are shown in figure 2. A total of 2,490 serum samples were analysed and the overall sero-positivity across all districts was $20.1 \%$. The study showed that six (18.8\%) districts had very high PPR sero-prevalences of which four $(66.7 \%)$ belonged to the semi-arid ecological zone (Chamwino, Kondoa, Mvomero and Kilosa) and two (33.3\%) were from the coastal ecological zone (Bagamoyo and Mkuranga). Three districts (9.4\%; Shinyanga, Meatu and Iramba) had high PPR sero-prevalence, all from the semi-arid ecological zone. Magnitudes of PPR sero-prevalences for other districts are shown in table 1. Kruskal-Wallis H test showed that there was a statistically significant difference in sero-positivity between the three ecological zones, $\chi^{2}(2)=9.121, p=0.010$, with a mean rank sero-positivity of $24.7 \%$ for coastal zone, $12.0 \%$ for plateaux and $20.8 \%$ for semiarid zone. Post hoc pairwise comparisons showed a statistically significant difference in seroprevalence between plateau and semi-arid ecological zones $(p=0.032)$. Although the coastal ecological zone had a higher mean rank sero-positivity than the plateau ecological zone, there was no statistically significant difference between them $(p=0.083)$. Likewise, no statistically significant difference was found in sero-positivity between the coastal and semiarid ecological zones $(p=0.518)$.

Table 1: PPR sero-prevalence (\%) and sero-prevalence magnitude in study districts and ecological zones

\begin{tabular}{lrlll} 
District & Seropositivity $\mathbf{( \% )}$ & Level & Ecological zone & Production system \\
\hline Mvomero & 75 & Very high & Semi-arid & PastoAgropasto \\
Kilosa & 63.8 & Very high & Semi-arid & PastoAgropasto \\
Bagamoyo & 35.2 & Very high & Coast & PastoAgropasto \\
Mkuranga & 47.8 & Very high & Coast & AgroPasto \\
Kisarawe & 4.4 & Low & Coast & AgroPasto \\
Misenyi & 5 & Low & plateaux & AgroPasto \\
Karagwe & 0 & Zero & plateaux & AgroPasto \\
\hline
\end{tabular}




\begin{tabular}{lrlll}
\hline Ngara & 2.8 & Low & plateaux & AgroPasto \\
Kahama & 3.5 & Low & Semi-arid & AgroPasto \\
Shinyanga & 10.7 & High & Semi-arid & AgroPasto \\
Maswa & 0 & Zero & Semi-arid & AgroPasto \\
Meatu & 15.2 & High & Semi-arid & AgroPasto \\
Ukerewe & 0 & Zero & Plateaux & AgroPasto \\
Sengerema & 9.8 & Low & Plateaux & AgroPasto \\
Misungwi & 5 & Low & Plateaux & AgroPasto \\
Kwimba & 0 & Zero & Plateaux & AgroPasto \\
Magu & 1.9 & Low & plateaux & AgroPasto \\
Ilemela & 3.8 & Low & plateaux & AgroPasto \\
Nyamagana & 2 & Low & plateaux & AgroPasto \\
Chamwino & 53.5 & Very high & Semi-arid & AgroPasto \\
Kondoa & 33.5 & Very high & Semi-arid & AgroPasto \\
Iramba & 14.1 & High & Semi-arid & AgroPasto \\
Singida & 7.3 & Low & Semi-arid & AgroPasto \\
Kigoma rural & 0 & Zero & Plateaux & AgroPasto \\
Kasulu & 0 & Zero & Plateaux & AgroPasto \\
Kibondo & 0 & Zero & Plateaux & AgroPasto \\
Igunga & 0 & Zero & Semi-arid & AgroPasto \\
Nzega & 0 & Zero & Semi-arid & AgroPasto \\
Tabora & 5 & Low & Plateaux & AgroPasto \\
Nsimbo & 5.9 & Low & Plateaux & AgroPasto \\
Mpanda & 0 & Zero & Plateaux & AgroPasto \\
Mlele & 0 & Zero & Plateaux & AgroPasto \\
\hline
\end{tabular}




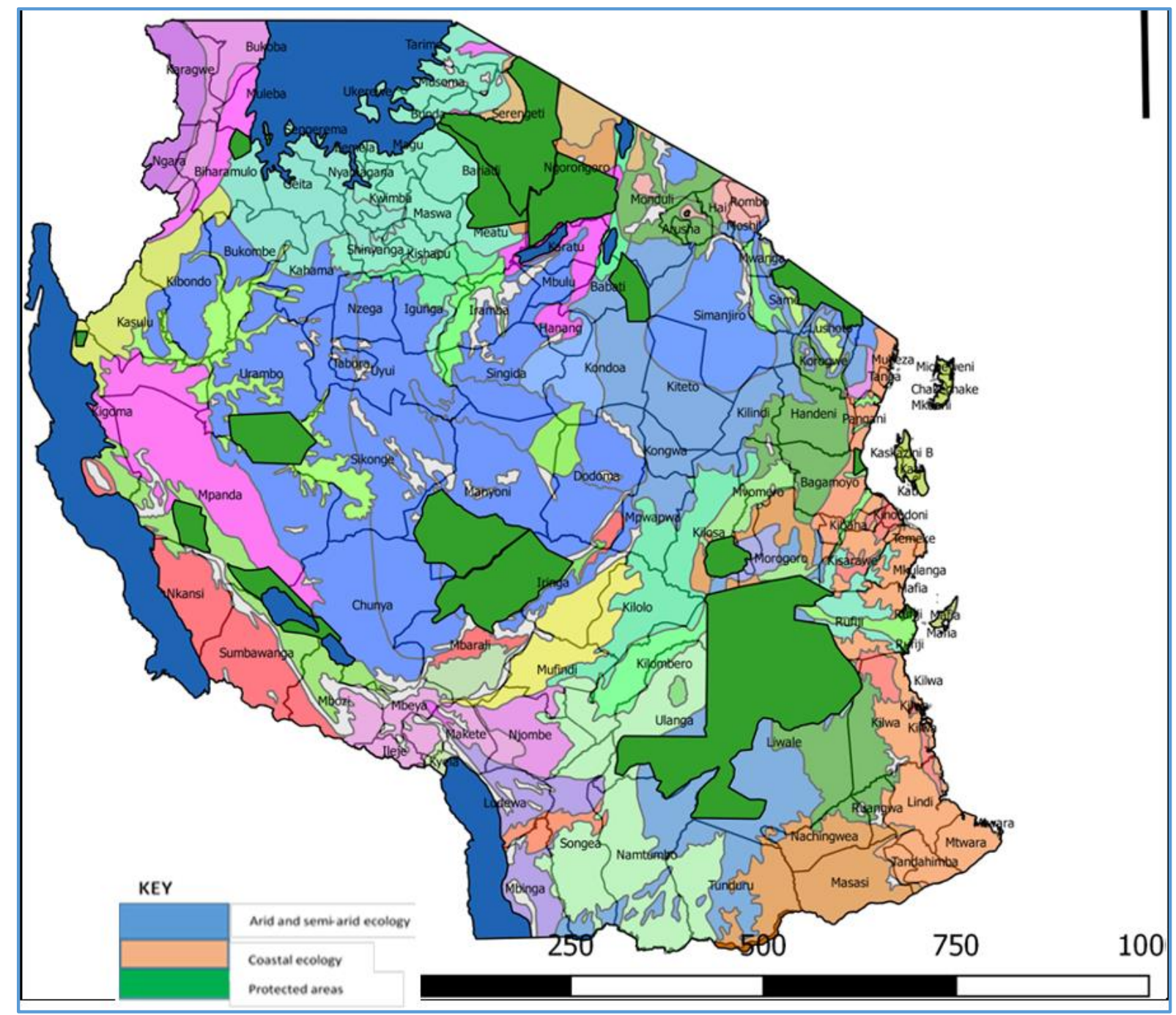

Figure 1: Tanzania map showing districts with respective ecological zones

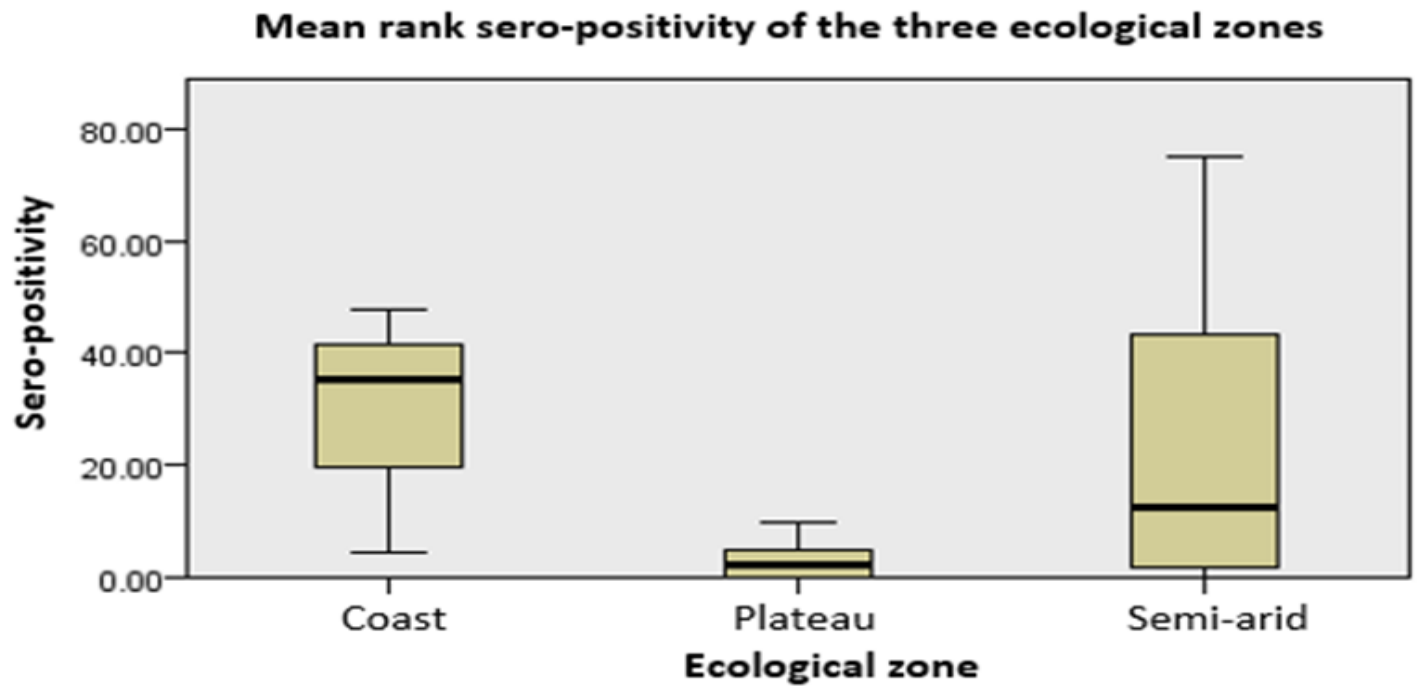

Figure 2: Mean rank sero-positivity of the three ecological zones 


\section{Discussion}

The present study was aimed at determining the differences in sero-prevalence of PPR in districts from different agro-ecological zones of Tanzania with unknown disease status. Samples were collected in areas where PPR surveillance activities had never been carried out before since confirmation of the disease in Tanzania in the year 2008. Analysis of 2,490 samples from sheep and goats confirmed the endemic nature and wide distribution of PPR throughout Tanzania. Results have shown that PPR sero-prevalence in the country is very high in magnitude in the semi-arid and coastal ecological zones. These findings are in line with what has been reported in previous studies carried out in the country, where PPR sero-prevalence were found to be higher in arid and semi-arid districts of Ngorongoro, Longido, Simanjiro and Monduli (Kivaria et al., 2014; Swai et al., 2009), as well as coastal districts of Lindi and Mtwara (Franklin et al., 2015; Kivaria et al., 2014; Muse et al., 2012). Similarly, in other parts of the East African region, studies have shown PPR seroprevalence to be higher in arid and semi-arid areas. This includes studies conducted in Turkana and Karamoja in Kenya and Uganda, respectively (Nkamwesiga et al., 2019; Dundon et al., 2017; Gitao et al., 2014; Kihu et al., 2015; Ruhweza et al., 2010). In Nigeria, sero-survey of PPRV in small ruminants from different ecological zones showed that the states found on savannah areas, which are ecologically similar to arid and semi-arid zones, had higher PPR sero-prevalence compared to states in the tropical rain forest and plateau (Woma et al., 2016). According to Lefèvre and Diallo (1990), PPRV infections persist in regions of low relative humidity, and that the PPRV survives longer in dry regions (Morandell et al., 2008). The mentioned attributes are a characteristic of the zones found to have higher sero-prevalence in this study, and therefore their observations are in support of the findings of the current study.

Over the years, arid and semi-arid areas in Tanzania have been a home for pastoralists. These areas have as well been preferred by wildlife, and also used in establishment of conserved areas such as national parks, game controlled areas or wildlife management areas (Kideghesho \& Msuya, 2012). This is because these areas are good at having animal feed resources like pasture, water and mineral licks in the soil as they have been conserved for a long time (Kideghesho et al., 2013). Since the areas are not suitable for crop farming, livestock keepers, especially pastoralists from different places take their animals for grazing on such areas. They sometimes take their animals to the boundaries of conserved areas and even inside particularly during the dry period when looking for pasture, water and mineral licks (Kideghesho \& Msuya, 2012). In so doing, livestock from different places and herds are gathered on the area, facilitating transmission of infectious diseases among the animals. This partly supports the observation in this study on higher prevalence of PPR in these areas as opposed to other ecological zones where animal populations are fairly small and interactions between animals from different places and herds are seldom. Hence, minimizing contact between animals from different places and herds could be considered in attempts to control this devastating disease. Moreover, PPR investigation in wildlife mingling with small ruminants in the protected and interface areas is necessary because the role of wildlife in the epidemiology of PPR is not well established which presents a gap in understanding the epidemiology of the disease. If the disease spills over to wildlife and is maintained and circulates among wildlife species it will be much more difficult to control than when it is only in the livestock population which is easy to manage.

Sheep and goat production is gaining its importance among pastoralists as grazing and watering areas are shrinking in their territories, because of climate change and changes of land use policy among different stakeholders. Such a change of situation is forcing pastoralists to shift from cattle production, which has higher demands for pasture and water to small ruminants, which are hardy, and have less demands for pasture and water. In some occasions, due to climate change, livestock keepers are forced to leave areas known to be their territories in arid and semi-arid areas to other areas looking for water and pasture. Since 2006 many pastoralists have been moving to coastal areas because of availability of grazing land. The influx of livestock from different places into the coastal zone, which was not previously used for livestock production, could be responsible for PPR introduction into the area. This is exacerbated by absence of animal health checks as the animals get into these new areas due to several reasons which include 
shortage of workforce as well as inadequate enforcement of laws that are in support of disease control. Eventually, following introduction of the disease, its further spread was facilitated through animal interactions which are highly supported by the prevailing extensive animal husbandry system, hence the observed high PPR sero-prevalence in the zone. Animal movements and interactions result into considerable changes in the epidemiological patterns of not only PPR but also of other infectious diseases.

Our findings point out to a relatively lower seroprevalence of PPR in ecological zones characterized by a more humid environment as compared to those featured by less humid environments. These areas are favourable for crop production and therefore communities are mainly involved in crop production. Consequently, these areas have very few livestock, including goats and sheep, and hence limited chances for contacts between animals from different herds. This makes chances of PPR transmission in these areas to be minimal compared to the arid and semi-arid areas which are preferred by pastoralists and agropastoralists due to lower level of crop production activities, which also prevents occurrence of conflicts between crop producers and livestock keepers. Thus, the lower livestock numbers in the humid environments, mostly used in crop production, could partly account for the lower sero-prevalence of PPR in the ecological zones.

Results of the present study may have been biased by the sampling method employed and the small sample size adopted. As the selection of zones was based on higher sheep and goat populations, and lack of previous studies on the epidemiology of PPR, this resulted into inadequate coverage as eventually only three ecological zones were involved. These criteria prevented obtaining useful information from other zones which were not involved in the study, that could lead to a fair comparison and provide a more comprehensive picture of the distribution of the disease in the country. This limitation could however be addressed by the use of the existing information to build spatial and temporal models that could be used in a cost-effective manner to determine the presence and extent of the disease in other zones for comparison purposes.
A total of 32 districts were investigated for the occurrence and extent of PPR infections among goat populations in the current study. All these were the districts in which there was no prior knowledge in their status with respect to PPR infections in the goat populations. Out of the studied districts, about two thirds (65.6\%) turned out to be positive for the disease. Six of the positive districts $(18.8 \%)$ had very high PPR sero-prevalence whereas three of them $(9.4 \%)$ had high PPR sero-prevalence. This finding is worth noting as it implies that the PPRV is widespread among goat populations in the country, as data are available for occurrence of the disease in many other districts across the country. This should present a wake-up call among authorities responsible for animal health as well as other stakeholders in the livestock sector that concerted efforts are required to combat livestock diseases especially those of significant socio-economic impacts to small holder farming communities. Activities focusing on preventing disease spread through breaking the weakest links in the transmission cycles should be given due priority. This imply changes in the animal husbandry systems and strengthening animal health service delivery by reaching rural farmers.

An important finding in the present study was a zero PPR sero-prevalence in three districts in the semi-arid zone and eight districts in the plateau ecological zone. From the disease control point of view, this is good news as these districts could be considered in the formation of disease free zones which could be considered in the production of disease free small ruminants for the export market. This technique has been adopted elsewhere in which zoning has been opted in the production of disease free animals for export so as to be able to reach the export market which is featured by stringent conditions including requiring exporting countries to be free from transboundary animal diseases. This would however require an additional work of screening the small ruminant populations in these districts for other equally important transboundary animal diseases which present an obstacle in reaching the export market. Generally, the control and eradication of PPR and other economically important small ruminant diseases is vital in order to alleviate poverty and improve the health and husbandry of small ruminant populations kept by people in resource limited settings. 


\section{Conclusion}

The occurrence of PPR in the country shows ecological zone pre-disposition, with seroprevalence being higher in semi-arid and coastal zones characterized by low relative humidity. This is suggestive of the prevalence of favourable conditions for survival and perpetuation of the virus among reservoir hosts and the susceptible goat populations in these areas. Control or eradication strategies for the disease should consider putting more efforts in these high risk areas as determined by the disease prevalence rates. The aim is to enhance informed decision making on disease control strategy.

\section{References}

Abubakar, M., \& Munir, M. (2014). Peste des Petits Ruminants virus: An emerging threat to goat farming in Pakistan. Transboundary and Emerging Diseases, 61(SUPPL1.), 7-10. https:// doi.org/10.1111/tbed.12192

Anderson, J., \& McKay, J. A. (1994). The detection of antibodies against peste des petits ruminants virus in cattle, sheep and goats and the possible implications to rinderpest control programmes. Epidemiology and Infection, 112(1), 225-231. https://doi.org/10.1017/S0950268800057 599

Baazizi, R., Mahapatra, M., Clarke, B. D., AitOudhia, K., Khelef, D., \& Parida, S. (2017). Peste des petits ruminants (PPR): A neglected tropical disease in maghreb region of North Africa and its threat to Europe. PLoS ONE, 12(4). https:// doi.org/10.1371/journal.pone.017 5461

Bao, J., Wang, Z., Li, L., Wu, X., Sang, P., Wu, G., ... Qi, L. (2011). Detection and genetic characterization of peste des petits ruminants virus in free-living bharals (Pseudois nayaur) in Tibet, China. Research in Veterinary Science. https://doi.org/10.1016/j.rvsc.2010.05.03 1

Baron, J., Bin-Tarif, A., Herbert, R., Frost, L., Taylor, G., \& Baron, M. D. (2014). Early changes in cytokine expression in peste des petits ruminants disease. Veterinary Research, $45(1)$. https://doi.org/10.1186/1297-9716-45-22

\section{Acknowledgements}

The study was supported by the United Nations Food and Agriculture Organization (FAO) project: Emergency assistance for early detection and control of PPR (PPR) TCP/URT/3302 (E), the Tanzanian government through the Ministry of Livestock and Fisheries, and The Southern African Centre for Infectious Disease (SACIDs) of Sokoine University of Agriculture (SUA) which are all highly thanked for their support. Moreover, my supervisors from SUA and the Royal Veterinary College London are gratefully acknowledged. The Global Challenge relief fund (GCRF) is acknowledged for financial support.

Baron, M. D., Diallo, A., Lancelot, R., \& Libeau, G. (2016). Peste des Petits Ruminants Virus. In Advances in Virus Research. https://doi.org/10.1016/bs.aivir.2016.02. 001

Baron, Michael D. (2015). The molecular biology of peste des petits ruminants virus. In Peste Des Petits Ruminants Virus. https:// doi.org/10.1007/978-3-662-451656_2

Baron, Michael D., Diop, B., Njeumi, F., Willett, B. J., \& Bailey, D. (2017). Future research to underpin successful peste des petits ruminants virus (PPRV) eradication. Journal of General Virology. https://doi.org/10.1099/jgv.0.000944

Bölske, G., Mattsson, J. G., Bascunana, C. R., Bergström, K., Wesonga, H., \& Johansson, K. E. (1996). Diagnosis of contagious caprine pleuropneumonia by detection and identification of Mycoplasma capricolum subsp. capripneumoniae by PCR and restriction enzyme analysis. Journal of Clinical Microbiology. https://doi.org/10.1128/jcm.34.4.785791.1996

Cg, G., Kihu S, \& Sm, M. (2016). Review of Peste Des Petits Ruminants in Sheep. J Vet Med Res.

Chauhan, H. C., Chandel, B. S., Kher, H. N., Dadawala, A. I., \& Agrawal, S. M. (2009). Pesti des petits ruminants virus infection in animals. Veterinary World. https:// doi.org/10.5455/vetworld.2009.1 50-155

Couacy-Hymann, E., Bodjo, S. C., Danho, T., 
Koffi, M. Y., Libeau, G., \& Diallo, A. (2007). Early detection of viral excretion from experimentally infected goats with pestedes-petits ruminants virus. Preventive Veterinary Medicine, 78(1), 85-88. https:// doi.org/10.1016/j.prevetmed.200 6.09.003

Devendra, C., \& McLeroy, G. B. (1982). Goat and sheep production in the Tropics. Goat and Sheep Production in the Tropics. https:// doi.org/10.1016/09214488(94)90018-3

Diallo, A. (2006). Control of peste des petits ruminants and poverty alleviation? Journal of Veterinary Medicine Series B: Infectious Diseases and Veterinary Public Health. https://doi.org/10.1111/j.14390450.2006.01012.x

Dundon, W. G., Kihu, S. M., Gitao, G. C., Bebora, L. C., John, N. M., Oyugi, J. O., ... Diallo, A. (2017). Detection and Genome Analysis of a Lineage III Peste Des Petits Ruminants Virus in Kenya in 2011. Transboundary and Emerging Diseases, 64(2), 644-650. https://doi.org/10.1111/tbed.12374

El Hassan, S. M., Harbi, M. S. M. A., \& Bakr, M. I. A. (1984). Treatment of contagious caprine pleuropneumonia. Veterinary Research Communications. https://doi.org/10.1007/BF02214697

FAO, \& OIE. (2015). Global strategy for the control and eradication of PPR. International conference for the control and eradication of Peste des Petits Ruminants (PPR). Abidjan, Ivory Coast.

Fournié, G., Waret-Szkuta, A., Camacho, A., Yigezu, L. M., Pfeiffer, D. U., \& Roger, F. (2018). A dynamic model of transmission and elimination of peste des petits ruminants in Ethiopia. Proceedings of the National Academy of Sciences. https://doi.org/10.1073/pnas.1711646115

Franklin, S. \&, Misinzo, G., Kgotlele, T., Muse, E. A., Doorsselaere, J. Van, Berg, M., \& Munir, M. (2015). Short Communication. British Journal of Virology, 2(1).

Gitao CG, Ithinji DG, Gitari R, \& Ireri GR. (2014). The confirmation of Peste des petit ruminants (PPR) in Kenya and perception of the disease in West Pokot. Res. Opin. Anim. Vet. Sci, 4(6), 312-317. Retrieved from http://www.roavs.com/pdffiles/Issue-6-2014/312-317.pdf

Khalafalla, A. I., Saeed, I. K., Ali, Y. H., Abdurrahman, M. B., Kwiatek, O., Libeau, G., ... Abbas, Z. (2010). An outbreak of peste des petits ruminants (PPR) in camels in the Sudan. Acta Tropica, 116(2), 161-165. https://doi.org/10.1016/j.actatropica.201 0.08 .002

Kideghesho, J. R., \& Msuya, T. S. (2012). Managing the Wildlife Protected Areas in the Face of Global Economic Recession, HIV / AIDS Pandemic, Political Instability and Climate Change: Experience of Tanzania.

Kideghesho, J. R., Rija, A. A., Mwamende, K. A., \& Selemani, I. S. (2013). Emerging issues and challenges in conservation of biodiversity in the rangelands of Tanzania. Nature Conservation, 6(November), 1-29. https://doi.org/10.3897/natureconservat ion.6.5407

Kihu, S. M., Gachohi, J. M., Ndungu, E. K., Gitao, G. C., Bebora, L. C., John, N. M., ... Ireri, R. (2015). Sero-epidemiology of Peste des petits ruminants virus infection in Turkana County, Kenya. BMC Veterinary Research, 11(1). https:// doi.org/10.1186/s12917-0150401-1

Kinne, J., Kreutzer, R., Kreutzer, M., Wernery, U., \& Wohlsein, P. (2010). Peste des petits ruminants in Arabian wildlife. Epidemiology and Infection, 138(8), 12111214. https://doi.org/10.1017/S0950268809991 592

Kipronoh, K. A., Ombui, J. N., Binepal, Y. S., Wesonga, H. O., Gitonga, E. K., Thuranira, E., \& Kiara, H. K. (2016). Risk factors associated with contagious caprine pleuropneumonia in goats in pastoral areas in the Rift Valley region of Kenya. Preventive Veterinary Medicine, 132. https:// doi.org/10.1016/j.prevetmed.201 6.08 .011

Kivaria, F. M., Kwiatek, O., Kapaga, A. M., Swai, E. S., Libeau, G., Moshy, W., ... Gladson, J. (2014). The incursion, persistence and spread of peste des petits ruminants in Tanzania: Epidemiological patterns and predictions. Onderstepoort Journal of Veterinary Research, 81(1). https:// doi.org/10.4102/ojvr.v80i1.593

Kock, R. A., Orynbayev, M. B., Sultankulova, K. T., Strochkov, V. M., Omarova, Z. D., Shalgynbayev, E. K., ... Parida, S. (2015). Detection and Genetic Characterization of Lineage IV Peste Des Petits Ruminant Virus in Kazakhstan. Transboundary and Emerging

Diseases. 
https://doi.org/10.1111/tbed.12398

Kumar, N., Chaubey, K. K., Chaudhary, K., Singh, S. V., Sharma, D. K., Gupta, V. K., ... Sharma, S. (2013). Isolation, identification and characterization of a Peste des Petits Ruminants virus from an outbreak in Nanakpur, India. Journal of Virological Methods, $\quad$ 189(2), 388-392. https://doi.org/10.1016/j.jviromet.2013.0 3.002

Mahapatra, M., Sayalel, K., Muniraju, M., Eblate, E., Fyumagwa, R., Shilinde, L., ... Kock, R. (2015). Spillover of Peste des Petits Ruminants Virus from Domestic to Wild Ruminants in the Serengeti Ecosystem, Tanzania. Emerging Infectious Diseases, 21(12), 2230-2234. https://doi.org/10.3201/eid2112.150223

Malik, Y. S., Singh, D., Chandrashekar, K. M., Shukla, S., Sharma, K., Vaid, N., \& Chakravarti, S. (2011). Occurrence of dual infection of peste-des-petits-ruminants and goatpox in indigenous goats of central India. Transboundary and Emerging Diseases. https://doi.org/10.1111/j.18651682.2011.01201.x

Morandell, S., Stasyk, T., Skvortsov, S., Ascher, S., \& Huber, L. A. (2008). Quantitative proteomics and phosphoproteomics reveal novel insights into complexity and dynamics of the EGFR signaling network. Proteomics, 8(21), 4383-4401. https://doi.org/10.1002/ pmic.200800204

Munir, M. (2014a). Role of wild small ruminants in the epidemiology of peste des petits ruminants. Transboundary and Emerging Diseases.

https://doi.org/10.1111/tbed.12052

Munir, M. (2014b). Role of wild small ruminants in the epidemiology of peste des petits ruminants. Transboundary and Emerging Diseases.

https://doi.org/10.1111/tbed.12052

Muse, E. A., Matondo, R. B., Karimuribo, E. D., Misinzo, G., Albano, M. O., \& Gitao, G. C. (n.d.). Clinico-pathological findings of the 2011 outbreak of Peste des Petits Ruminants (PPR) in Tandahimba district, southern Tanzania. Res. Opin. Anim. Vet. Sci, 2(4), 256-262.

Nkamwesiga, J., Coffin-Schmitt, J., Ochwo, S., Mwiine, F. N., Palopoli, A., Ndekezi, C., ... Mariner, J. C. (2019). Identification of peste des petits ruminants transmission hotspots in the Karamoja subregion of Uganda for

Shirima, G. M. (2005). The epidemiology of targeting of eradication interventions. Frontiers in Veterinary Science, 6(JUL), 1-13. https://doi.org/10.3389/fvets.2019.00221

Orynbayev, M. B., Beauvais, W., Sansyzbay, A. R., Rystaeva, R. A., Sultankulova, K. T., Kerimbaev, A. A., ... Kock, R. A. (2016). Seroprevalence of infectious diseases in saiga antelope (Saiga tatarica tatarica) in Kazakhstan 2012-2014. Preventive Veterinary Medicine, 127, 100-104. https://doi.org/10.1016/j.prevetmed.201 6.03.016

Ruhweza, S. ., Ayebazibwe, C., Mwiine, F. ., Muhanguzi, D., \& Olaho, W. (2010). Seroprevalence of Peste des Petits Ruminants (PPR) virus antibodies in goats and sheep in north-eastern Uganda. Bulletin of Animal Health and Production in Africa, $58(2)$. https:/ / doi.org/10.4314/bahpa.v58i2.620 48

Rurangirwa, F. R., McGuire, T. C., Mbai, L., Ndung'u, L., \& Wambugu, A. (1991). Preliminary field test of lyophilised contagious caprine pleuropneumonia vaccine. Research in Veterinary Science, 50(2), 240-241.

https:/ / doi.org/10.1016/00345288(91)90114-4

Saeed, I. K., Ali, Y. H., AbdulRahman, M. B., Mohammed, Z. A., Osman, H. M., Taha, K. M., ... Khalafalla, A. M. I. (2015). Mixed infection of peste des petits ruminants virus (PPRV) and other respiratory viruses in dromedary camels in Sudan, an abattoir study. Tropical Animal Health and Production, 47(5), 995-998. https://doi.org/10.1007/s11250-0150798-3

Sen, A., Saravanan, P., Balamurugan, V., Bhanuprakash, V., Venkatesan, G., Sarkar, J., ... Singh, R. K. (2014). Detection of subclinical peste des petits ruminants virus infection in experimental cattle. VirusDisease.

https://doi.org/10.1007/s13337-0140213-0

Shatar, M., Khanui, B., Purevtseren, D., Khishgee, B., Loitsch, A., Unger, H., ... Dundon, W. G. (2017). First genetic characterization of peste des petits ruminants virus from Mongolia. Archives of Virology. https://doi.org/10.1007/s00705-0173456-4 brucellosis in animals and humans in Arusha 
and Manyara regions in Tanzania. Thesis submitted for the degree of Doctor of Philosophy Department of Veterinary Clinical Studies Faculty of Veterinary Medicine University of Glasgow. https://doi.org/10.1007/978-1-4614-79901

Singh, R. (2011). Control strategies for peste des petits ruminants in small ruminants of India. Rev Sci Tech Off Int Epiz. https://doi.org/10.20506/rst.30.3.2079

Swai, E. S., Kapaga, A., Kivaria, F., Tinuga, D., Joshua, G., \& Sanka, P. (2009). Prevalence and distribution of Peste des petits ruminants virus antibodies in various districts of Tanzania. Veterinary Research Communications, 33(8), 927-936. https://doi.org/10.1007/s11259-0099311-7

Taylor, W. P., \& Barrett, T. (1946). DISEASES of sheep. Veterinary medicine (Vol. 41). https://doi.org/10.1002/9780470753316.c h61

Travis, D. a, Watson, R. P., \& Tauer, A. (2011). The spread of pathogens through trade in wildlife. OIE Revue Scientifique et Technique, 30(1),

219-239.

petits ruminants (PPR) in camels (Camelus dromedarius) in Iran. Tropical Animal Health and Production, 48(6), 1215-1219. https:/ / doi.org/10.3201/eid1107.050194

Truong, T., Boshra, H., Embury-Hyatt, C., Nfon, C., Gerdts, V., Tikoo, S., ... Babiuk, S. (2014). Peste des petits ruminants virus tissue tropism and pathogenesis in sheep and goats following experimental infection. PLOS ONE, 9(1). https://doi.org/10.1371/journal.pone.008 7145

Wernike, K., Eschbaumer, M., Breithaupt, A., Maltzan, J., Wiesner, H., Beer, M., \& Hoffmann, B. (2014). Experimental infection of sheep and goats with a recent isolate of peste des petits ruminants virus from Kurdistan. Veterinary Microbiology. https:/ / doi.org/10.1016/j.vetmic.2014.05. 010

Woma, T. Y., Ekong, P. S., Bwala, D. G., Ibu, J. O., Ta'Ama, L., Dyek, D. Y., ... Quan, M. (2016). Serosurvey of peste des petits ruminants virus in small ruminants from different agro-ecological zones of Nigeria. Onderstepoort Journal of Veterinary Research. https://doi.org/10.4102/ojvr.v83i1.1035

Zakian, A., Nouri, M., Kahroba, H., Mohammadian, B., \& Mokhber-Dezfouli, M. R. (2016). The first report of peste des https:/ / doi.org/10.1007/s11250-0161078-6 